\title{
INDISIM-SOM, AN INDIVIDUAL-BASED MODEL TO STUDY SHORT- TERM EVOLUTIONS OF CARBON AND NITROGEN POOLS RELATED TO MICROBIAL ACTIVITY IN SOIL ORGANIC MATTER
}

\author{
Anna Gras \\ College of Agricultural Engineering of Barcelona \\ Technical University of Catalonia \\ Campus Baix Llobregat, Avinguda Canal Olimpic s/n \\ 08860-Castelldefels (Barcelona), Spain \\ E-mail: anna.gras@upc.es
}

\author{
Marta Ginovart \\ Department of Applied Mathematics III \\ Technical University of Catalonia \\ Campus Baix Llobregat, Avinguda Canal Olimpic s/n \\ 08860-Castelldefels (Barcelona), Spain \\ E-mail: marta.ginovart@upc.es
}

\section{KEYWORDS}

Discrete simulation, individual-based model, microbial activity, carbon, nitrogen, soil organic matter.

\begin{abstract}
This work deals with the implementation of a soil organic matter model in an individual-based modelling framework. The simulator INDISIM-SOM models the dynamics of carbon and nitrogen related to soil organic matter and the soil microbial activity by using a discrete simulation. This simulation model controls the activity of group of microbial cells in a space divided into square cells where amounts of different types of organic compounds are also controlled. Different metabolic pathways and sources of $\mathrm{C}$ and $\mathrm{N}$ the microorganisms can use are identified. INDISIM-SOM deals with the mineralization and nitrification of $\mathrm{C}$ and $\mathrm{N}$ and, the activity of heterotrophic microorganisms and nitrifier bacteria. The calibration of the simulation model has made use of data from laboratory incubation experiments performed on three different types of Mediterranean soils.
\end{abstract}

\section{INTRODUCTION}

Individual-based Models (IbM's) are simulations based on the global consequences of local interactions of members of a population. These individuals might represent plants and animals in ecosystems or cells in microbial systems. These models typically represent an environment or framework in which the interactions happen and a number of individuals are defined in terms of their behaviours (procedural rules) and their biological parameters. In an individual-based model (IbM) the characteristics of each individual are tracked through time. This stands in contrast to modelling techniques where the characteristics of the population are averaged together and the model attempts to simulate changes in these averaged characteristics for the whole population. Individual-based models are also known as entity or agent based models, and as individual/entity/agent-based simulations. Some IbMs are also spatially explicit, meaning that the individuals are associated with a location in a geometrical space. IbMs are a subset of agent based models which includes any computational system whose design is fundamentally composed of a collection of interacting parts. Individual-based models are distinguished by the fact that each "agent" corresponds to autonomous individual in the simulated domain (Crawford et al. 2005).

IbMs have become widely used in modelling populations dynamics since they were developed in the 1970s. They are built on the premise that individual entities populate the model work; interact with one another and then system patterns emerge as a result of those interactions. This makes them suitable for simulating population dynamics where individual organisms interact with one another and the environment. They can therefore be used to explore systems dynamics from the bottom-up. An individual based model was developed and designed by our research group to simulate the growth and behaviour of bacterial colonies (Ginovart et al. 2002a). The simulator was called INDISIM, which stands for INDividual DIScrete SIMulations and extensions and modifications of INDISIM have been carried out to improve the knowledge of diverse microbial systems (Ginovart et al. 2002b, 2002c, 2006).

Soil organic matter plays an important role in the development and functioning of terrestrial ecosystems. Microorganisms are the first colonizers of the soil and also the main agents responsible for the dynamics of carbon and nitrogen, for some steps of the $\mathrm{C}$ and $\mathrm{N}$ cycling (Chen et al. 2003). Bacteria are the most abundant microorganisms in soil, followed by fungi and algae. They use organic compounds as a source of $\mathrm{C}$ and $\mathrm{N}$ to synthesize their biomass and as a source of energy. They release mineral and organic compounds as 
end products of their metabolism, some of which are absorbed by the vegetal community living on the soil. In recent years there has been an increase in modelling and simulation studies on the transformations of $\mathrm{C}$ and $\mathrm{N}$ in soils (see, e.g., Garnier et al. 2003; Gignoux et al. 2001; Neergaard et al. 2002; Smith et al. 1997). The general outline of the applied methodology includes two main steps, the modelling the behaviour of biotic and abiotic elements in a spatial domain (microorganisms and substrate particles respectively), and after that, the implementation of the overall model in a computer code. We follow the behaviour of all biotic and abiotic elements acting together.

INDISIM-SOM (an extension of INDISIM) is an individual simulation model that enables us to study microbial activity in Soil Organic Matter (SOM), dealing with the mineralization and immobilisation of $\mathrm{C}$ and $\mathrm{N}$, and the integration of the nitrification process in this context. INDISIM-SOM is focused on the microbial activity, and assumes two different prototypes of microorganisms and nine different types of substrates. It also takes into account the role of $\mathrm{C}$ and $\mathrm{N}$ during their microbial lives, thus linking the $\mathrm{C}$ and $\mathrm{N}$ cycles. (Ginovart et al. 2001, 2005; Gras 2004; Gras and Ginovart 2004). To parameterize the model is necessary to get information about soil microbiota and biochemical process related to microbial nutrition, growth requirements and metabolic pathways followed by these microorganisms. After that a quantitative implementation of this simulator can be achieved. The calibration of the INDISIM-SOM has been shown feasible. The simulated evolutions of variables related to $\mathrm{C}$ and $\mathrm{N}$, together with those related to the microbial activity, are in agreement with short-term experimental evolutions under specific conditions. The first calibration of INDISIM-SOM was performed using experimental data from incubations of two different Catalonian soils, Calaf soil and Miralles soil (Ginovart et al. 2005).

The aim of this work is to show that after the scaling process and calibration, the simulations carried out with INDISIM-SOM are in a good agreement with experimental data obtained from laboratory incubation of another Mediterranean soil called Caldes. It is important to state that the same set of input values for parameters related to microbial population have been used for the simulations, despite the fact the input simulation data for parameters related to initial composition of these three simulated soils are different (Calaf, Miralles and Caldes).

\section{INDISIM-SOM SIMULATION MODEL}

Figure 1 shows the INDISIM-SOM sketch for mineralization and immobilisation of $\mathrm{C}$ and $\mathrm{N}$ because of the microbial activity. We assume in INDISIM-SOM two different prototypes of microbial cells, one group of heterotrophic microorganisms and another group of nitrifier bacteria. Their biomasses are identified as live pools, $\mathrm{CN}_{\mathrm{MIC}-\mathrm{H}}$ and $\mathrm{CN}_{\mathrm{MIC}-\mathrm{N}}$ respectively. We also consider different types of substrates, organic compounds namely: polymerised carbon $\left(\mathrm{C}_{\mathrm{P}}\right)$, polymerised nitrogen $\left(\mathrm{CN}_{\mathrm{P}}\right)$, labile carbon $\left(\mathrm{C}_{\mathrm{L}}\right)$, labile nitrogen $\left(\mathrm{CN}_{\mathrm{L}}\right)$ and humic compounds $\left(\mathrm{CN}_{\mathrm{H}}\right)$, and the others are mineral compounds, $\mathrm{N}_{\mathrm{NH} 4}, \mathrm{~N}_{\mathrm{NO} 3}, \mathrm{C}_{\mathrm{CO} 2}$ and $\mathrm{O}_{2}$. We model the evolution and behaviour of each prototype, taking into account the motion, uptake, metabolism, reproduction, death and lyses of the microbial cells. The model also takes in account some mass transfer processes, as the hydrolysis reactions of complex compounds to labile compounds, the output flow of $\mathrm{CO}_{2}$ from the system, the input flow of $\mathrm{O}_{2}$, and the diffusion of organic labile and mineral compounds in the medium.

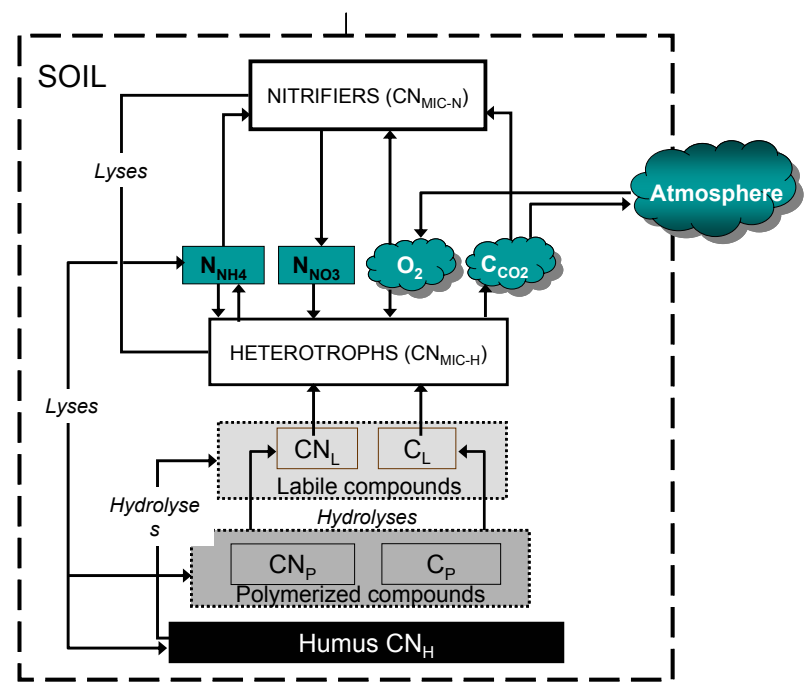

Figure 1: Sketch of mineralization and immobilisation of $\mathrm{C}$ and $\mathrm{N}$ and nitrification process due to the microbial activity in INDISIM-SOM.

The polymerized and humic pools have different decomposition rate, depending on its biochemical composition, and it is also modified according to the microbial biomass in the medium. Depending on the availability of labile organic matter and mineral compounds, the microorganisms choose one or another metabolic pathway to obtain energy and to synthesize biomass. So the viability of the microorganisms is subject to all of these considerations.

INDISIM-SOM controls a group of microorganisms at each time step, using a set of random, time dependent, variables for each cell to characterise: prototype (heterotroph or nitrifier), position in space, biomass, reproduction mass and state in the cellular reproduction cycle. A physical lattice, subdivided into spatial cells, is considered. Each one of these spatial cells is defined by a set of random, time dependent, variables that include the concentrations of each kind of substrate particles. The complete set of variables enables the simulator to study the behaviour of each microorganism according to 
given rules: (i) Motion (random assignment of a new position in the space domain); (ii) Uptake of particles of the different abiotic elements; (iii) Metabolism of these uptaken particles to assign the energy necessary for upkeep the cell (cellular maintenance energy), the synthesis of new biomass (Fig. 2), and the excretion to the medium of end particles; (iv) Reproduction, with previous checking of the conditions for the cellular duplication; (v) Lyses of the cell if the conditions to die are satisfied, with the releasing of microbial biomass to the medium. The different and periodically tasks for each spatial cell of the medium are: (i) Mass-transfer reactions from complex $\left(\mathrm{C}_{\mathrm{P}}, \mathrm{CN}_{\mathrm{P}}\right.$ and $\left.\mathrm{CN}_{\mathrm{H}}\right)$ to labile compounds $\left(\mathrm{C}_{\mathrm{L}}, \mathrm{CN}_{\mathrm{L}}\right)$; (ii) Remove the $\mathrm{C}_{\mathrm{CO} 2}$ particles to mimic such an outflow; (iii) Input flow of $\mathrm{O}_{2}$; (iv) Diffusion of labile and mineral compounds particles $\left(\mathrm{C}_{\mathrm{L}}, \mathrm{CN}_{\mathrm{L}}, \mathrm{N}_{\mathrm{NH} 4}, \mathrm{~N}_{\mathrm{NO} 3}, \mathrm{CO}_{2}\right.$ and $\left.\mathrm{O}_{2}\right)$, assuming that diffusion takes place according to Fick's relation, in two dimensions and discretized form. The polymerized compounds $\left(\mathrm{C}_{\mathrm{P}}, \mathrm{CN}_{\mathrm{P}}\right.$, and $\left.\mathrm{CN}_{\mathrm{H}}\right)$ remain in a fix position.

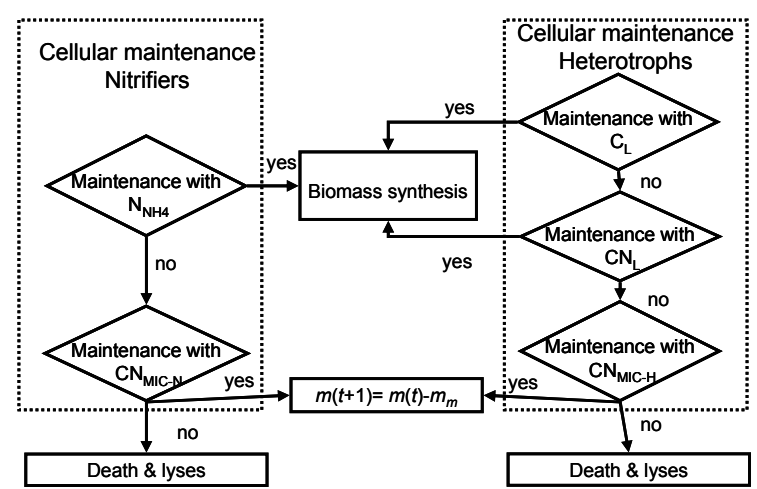

Figure 2. Sketch of metabolism for both groups of microorganisms to achieve cellular maintenance, increase of biomass and lyses depending on substrate uptake.

As a result of the preceding tasks on both the microorganisms and the particles of the abiotic elements, the system changes into a new configuration.

The generic aspects of INDISIM are discussed in Ginovart et al. (2002a) to which readers are referred, and the more specific aspects of INDISIM-SOM that provide short-term dynamics of $\mathrm{C}$ and $\mathrm{N}$, resulting from the following processes in soil like decomposition, mineralization, immobilisation and nitrification can be found in Ginovart et al. (2005).

\section{DATA ACQUISITION}

We have made use of data collected by Vidal (1995) from incubation experiments conducted under laboratory conditions. Three soils of Catalonia (Spain) with different organic matter content and sandy loam texture, Calaf, Miralles and Caldes, were incubated in darkness for 90 days at a constant temperature of $30^{\circ} \mathrm{C}$ and a moisture content to $80 \%$ water-holding capacity. Table 1 presents the specific properties of these soils. The analyses were performed on three replicates. For total soil $\mathrm{N}$, the $\mathrm{N}$-Kjeldahl method was used. In order to determine the easily hydrolysable $\mathrm{N}\left(\mathrm{N}_{\mathrm{h}}\right)$ the samples were distilled in an alkaline medium and the distillate fraction was collected in an acid solution (Vapodest $12 /$ Gerhardt). To determine the $\mathrm{CO}_{2}$, soil samples were incubated in a closed receptacle and the $\mathrm{CO}_{2}$ respired was trapped by the $\mathrm{NaOH}$, and the free $\mathrm{NaOH}$ was determined by back titration with $\mathrm{HCl}$ (Vidal 1995).

Table 1. Composition and characteristics of the three sampled Mediterranean soils.

\begin{tabular}{ccccc}
\hline & Unit & $\begin{array}{c}\text { Calaf } \\
\text { soil }\end{array}$ & $\begin{array}{c}\text { Miralles } \\
\text { soil }\end{array}$ & $\begin{array}{c}\text { Caldes } \\
\text { soil }\end{array}$ \\
\hline $\mathrm{pH}$ & & 7.2 & 7.3 & 7.2 \\
Organic C & $\mathrm{g} \mathrm{g}^{-1}$ & 0.02175 & 0.0116 & 0.0091 \\
$\mathrm{C} / \mathrm{N}$ & & 9.9 & 10.6 & 9.1 \\
Total N & $\mathrm{g} \mathrm{g}^{-1}$ & 0.0022 & 0.00116 & 0.001 \\
$\mathrm{~N}^{-\mathrm{NH}_{4}}{ }^{+}$ & $\mathrm{mg} \mathrm{g}^{-1}$ & 0.020 & 0.010 & 0.016 \\
$\mathrm{~N}^{-} \mathrm{NO}_{3}^{-}$ & $\mathrm{mg} \mathrm{g}^{-1}$ & 0.033 & 0.023 & 0.017 \\
Organic N $^{-}$ & $\mathrm{mg} \mathrm{g}^{-1}$ & 2.18 & 1.15 & 0.98 \\
Hydrolysable N & $\mathrm{mg} \mathrm{g}^{-1}$ & 0.150 & 0.086 & 0.054 \\
Clay & $\mathrm{o}^{-1}$ & 13 & 16 & 9 \\
\hline
\end{tabular}

\section{RESULTS AND DISCUSSION}

The sets of values given in tables 2, 3 and 4 determine the composition and characteristics of the three simulated soil systems corresponding to Calaf, Miralles and Caldes soils, the temporal evolutions of which will be compared with the three sets of experimental incubation data. Table 2 shows the input data for microbial parameters of the population model used in the three simulations. Some of them have been obtained from literature and assumed, or inferred, o fitted by trial and error, to achieve an overall and good visual fit of measured and simulated data used. The substrate availability, the maintenance energy and death probability are obtained by calibration based on shortterm incubation experiments. A more specific discussion of these parameters can be found in a previous paper (Ginovart et al. 2005). The scaling of the simulator INDISIM-SOM to carry out these simulations has been made, and the input and output data for microorganisms are close to values typically observed for bacterial populations in natural environments or in laboratory conditions (Gras 2004; Gras and Ginovart 2004; Ginovart et al. 2005). The common parameterisation chosen for the microbial population has succeeded in making a good agreement between the three simulations and their experimental data sets. Table 3 shows the size of each model pool used in these 
simulations, which depends on the partitioning coefficients that allow assigning the $\mathrm{C}$ and $\mathrm{N}$ to each organic pool and microbial biomass. The initial simulated microbial biomass $\mathrm{C}$ for Calaf, Miralles and Caldes soils are $0.015,0.018$ and $0.025 \mathrm{~g} \mathrm{C}_{\mathrm{MIC}} \mathrm{g}^{-1} \mathrm{C}_{\text {SOIL }}$ respectively. The partitioning coefficients as well as the ratio of microbial $\mathrm{C}$ to soil $\mathrm{C}$ are characteristics of each soil, and they are one of the main factors to fit the simulations to experimental data during the first stage of the evolution. The values of the decaying rates of the SOM-pools and flows gases rates are shown in Table 4.

Table 2. Input data for the microbial parameters of the population model used in the simulations.

\begin{tabular}{cccc}
\hline $\begin{array}{c}\text { Parameter } \\
\text { description }\end{array}$ & Unit & $\begin{array}{c}\text { Heterotrophic } \\
\text { microorganis }\end{array}$ & $\begin{array}{c}\text { Nitrifier } \\
\text { bacteria }\end{array}$ \\
\hline $\begin{array}{c}\text { Reproduction } \\
\text { mass }\end{array}$ & pmol & 2400 & 21.5 \\
$\begin{array}{c}\text { Minimum mass } \\
\text { Reproduction } \\
\text { time }\end{array}$ & $\mathrm{pmol}$ & 1920 & 16.8 \\
$\begin{array}{c}\text { Microbial } \\
\text { biomass C/N } \\
\text { ratio }\end{array}$ & $\mathrm{h}^{-1} \mathrm{~mol} \mathrm{C}^{-1} \mathrm{~N}$ & 1 & 1 \\
$\begin{array}{c}\text { Maintenance } \\
\text { energy }\end{array}$ & $\mathrm{gC} \mathrm{g}^{-1} \mathrm{C}_{\mathrm{MIC}} \mathrm{h}^{-1}$ & 0.004 & 0.008 \\
$\begin{array}{c}\text { Yield to the } \\
\text { synthesis of } \\
\text { biomass } \\
\begin{array}{c}\text { Death } \\
\text { probability }\end{array}\end{array}$ & $\mathrm{g} \mathrm{C}_{\mathrm{MIC}} \mathrm{g} \mathrm{C}$ & 0,6 & \\
$\begin{array}{c}\text { Humification } \\
\text { rate of } \\
\text { microbial } \\
\text { biomass }\end{array}$ & & 0.005 & 0.01 \\
\hline
\end{tabular}

The calibration of the simulator has been achieved by assigning values to all simulation parameters, mainly data for each microbial prototype and degradation rates for each organic pool. It is valid only under the conditions of the experiment and for mineral soil samples which has been dried sieved and rewetted. Such a mapping is not a trivial undertaking. Microbial parameter values used for the simulations presented in this paper were chosen to achieve an overall good fit. The simulation makes possible to study the time evolution of a large number of variables related to the soil-system. Microscopic and macroscopic variables may be analysed and discussed using the simulation output data. However, we only present here some results of our simulations in order to compare them with the three experimental evolutions of Calaf, Miralles and Caldes soils and discuss related issues.

The experimental data replicates are shown jointly with the simulation results. To study the evolution of the soil system has been defined the initial configuration for the simulated system: levels of heterotrophic and nitrifier populations with their microbiological properties, as well as a homogeneous distribution of the different substrates in the medium. We have carried out simulations in order to evaluate the response of the system, by controlling the behaviour of the different elements of the soil involved in the mineralization of the $\mathrm{C}$ and $\mathrm{N}$, and nitrification.

Table 3. Input data for the parameters related to initial composition of simulated soils. Units: $\times 10^{6} \mathrm{pmols} \mathrm{g}^{-1}$.

\begin{tabular}{cccc}
\hline Simulated pools & Calaf soil & Miralles soil & Caldes soil \\
\hline $\mathrm{C}_{\mathrm{P}}$ & 50.25 & 26.90 & 9.16 \\
$\mathrm{C}_{\mathrm{L}}$ & 3.49 & 3.67 & 4.93 \\
$\mathrm{CN}_{\mathrm{P}}$ & 0 & 0 & 0 \\
$\mathrm{CN}_{\mathrm{L}}$ & 7.41 & 4.19 & 2.79 \\
$\mathrm{CN}_{\mathrm{H}}$ & 144.05 & 75.33 & 64.65 \\
$\mathrm{~N}_{\mathrm{NH} 4}$ & 0.36 & 0.18 & 0.29 \\
$\mathrm{~N}_{\mathrm{NO} 3}$ & 2.36 & 1.64 & 1.21 \\
\hline
\end{tabular}

Table 4. Input simulation data for the parameters of mass-transfer reactions and output/input of gasses $\left(\mathrm{h}^{-1}\right)$.

\begin{tabular}{cc}
\hline Parameter description & Values \\
\hline Kinetic parameters of hydrolysis process & \\
$\mathrm{C}_{\mathrm{P}}$ to $\mathrm{C}_{\mathrm{L}}$ & 0.000025 \\
$\mathrm{CN}_{\mathrm{P}}$ to $\mathrm{CN}_{\mathrm{L}}$ & 0.000250 \\
$\mathrm{CN}_{\mathrm{H}}$ to $\mathrm{CN}_{\mathrm{L}}$ & 0.000018 \\
$\mathrm{CN}_{\mathrm{H}}$ to $\mathrm{C}_{\mathrm{L}}$ & 0.000027 \\
Output rate of $\mathrm{CO}_{2}$ & 1 \\
Input rate of $\mathrm{O}_{2}$ & 0.01 \\
\hline
\end{tabular}

Figure 3 shows the cumulative $\mathrm{CO}_{2}$ curves produced by the three soils which represent the microbial activity, and they are the consequence of the respiratory metabolism of heterotrophic microorganisms. Figure 4 shows the cumulative mineral $\mathrm{N}$ in the system. Carbon mineralization and nitrogen mineralization evolution in all studied soils show two different stages. The first one goes from the starting incubation until approximately $20^{\text {th }}$ day when a flush mineralization takes place. The flush in the $\mathrm{N}$ mineralization is little delayed in relation to $\mathrm{CO}_{2}$ production. At this period when labile organic $\mathrm{C}$ is available and most ammonium is reincorporated into the microbial biomass, the net $\mathrm{N}$ mineralization was very low. It seems that the labile organic matter that decomposed after wetting the dried sieved soil had a wide $\mathrm{C} / \mathrm{N}$ ratio that did not released any surplus of $\mathrm{N}$ to the inorganic pool (Hadas et al. 1992). Then, it is right to think that the main energetic source to the microbial population is the $\mathrm{C}_{\mathrm{L}}$ and that the $\mathrm{CN}_{\mathrm{L}}$ is incorporated into the microbial biomass. 

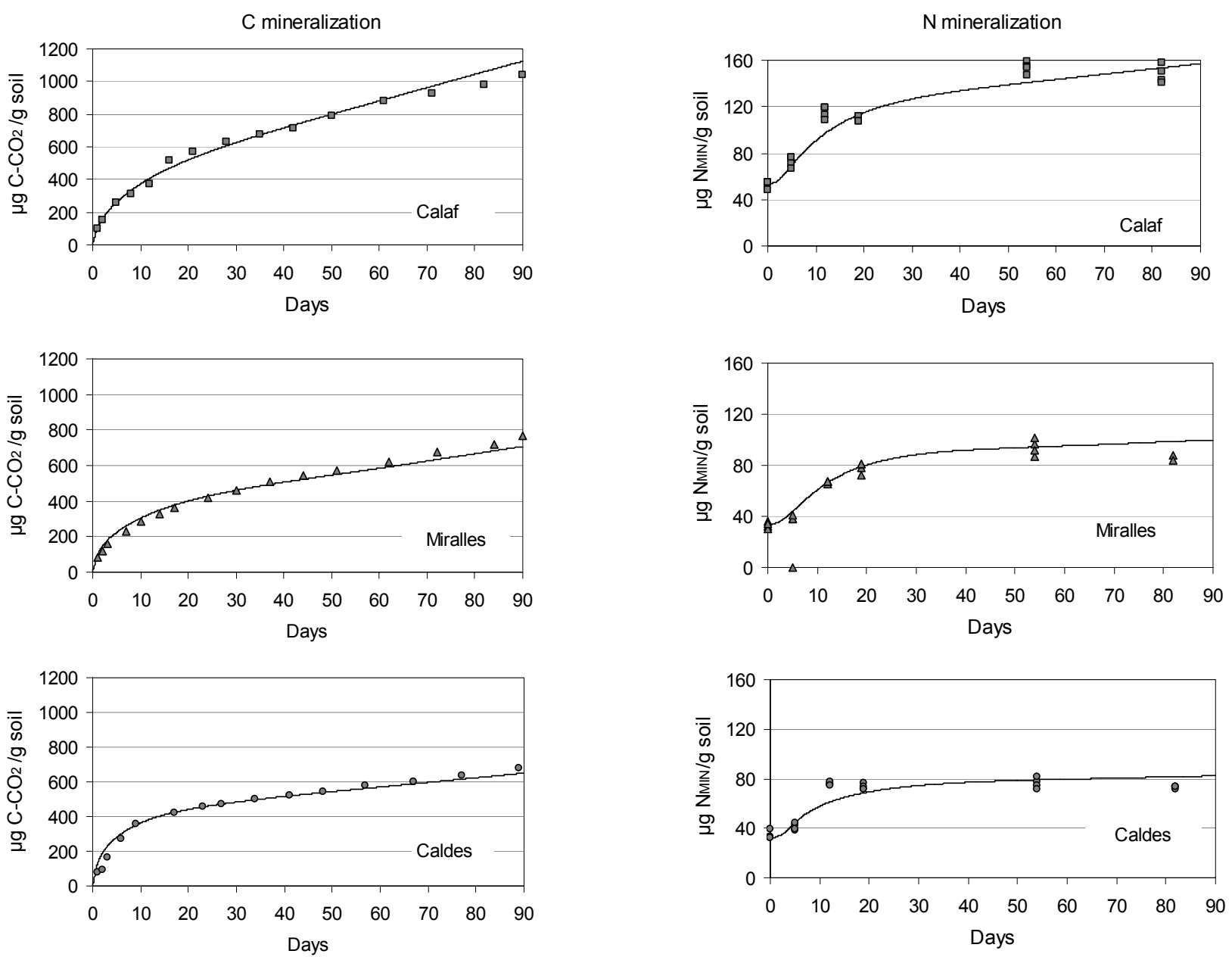

Figure 3: Cumulative $\mathrm{CO}_{2}$ produced: experimental data (points) and simulation results (lines) for the three soils fitted.

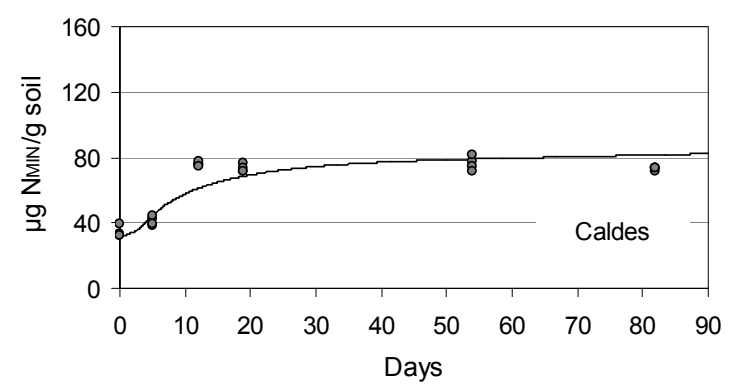

Figure 4: Net $\mathrm{N}$ mineralization in the three soils. Experimental data (points) and simulation results (lines) for the three soils fitted.
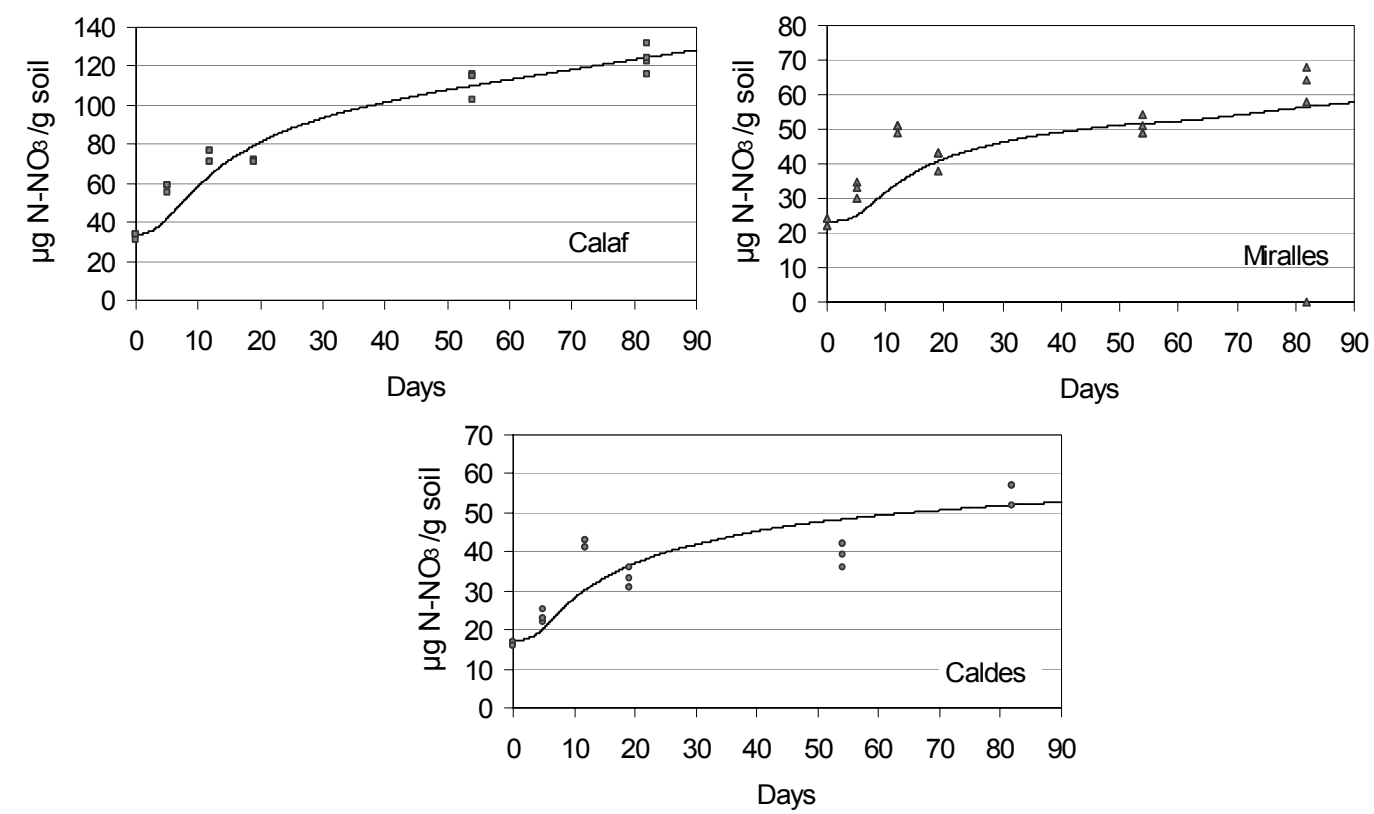

Figure 5: Cumulative Nitrate produced: experimental data (points) and simulations results (lines). 
Figure 5 shows the cumulative production of nitrate. It is possible to check a little delay in the nitrate production, the net production of $\mathrm{NO}_{3}{ }^{-}$starts after the $5^{\text {th }}$ day. The explanation of this phenomenon is that during these first days exists a high competence between both microbial population for $\mathrm{NH}_{4}^{+}$and oxygen (Bremmer and Mc Carty 1993, Nanippieri et al. 1990). When there are labile $\mathrm{C}$ compounds, the $\mathrm{NH}_{4}{ }^{+}$is immobilized into microbial biomass, but if the microbial heterotrophic growth is limited then the nitrification succeed (Schmidt 1982, Pansu 1998).

\section{REFERENCES}

Bremmer J.M.; and G. Mc Carty. 1993. "Inhibition of nitrification in soil by allelochemicals derived from plants and plant residues". In Soil Biochemistry 8. Bollag and Stotzky (Eds.). Marcel Dekker Inc. 181-218.

Chen G.; H. Zhu; and Y. Zhang. 2003. "Soil microbial activities and carbon and nitrogen fixation". Research in microbiology 154, 393-398.

Crawford T.C.; J.P. Messina; S.M. Manson; and D. O'Sullivan. 2005. "Complexity science, complex systems, and land-use research". Environment and Planning B: Planning and Design 32, 792-798.

Garnier P.; C. Néel; C. Aita; S. Recous; F. Lafolie; and B. Mary. 2003. "Modelling carbon and nitrogen dynamics in a bare soil with and without straw incorporation". European Journal of Soil Science 54, 555-568.

Gignoux J.; J. House; D. Hall; D. Masse; H.B. Nacro; and L. Abbadie. 2001. "Design and test of generic cohort model of soil organic matter decomposition: SOMKO model". Global Ecology \& Biogeography 10, 639-660.

Ginovart M.; A. Gras, and D. López. 2001. "Discrete simulation of bacterial activity in soils: amonification and nitrification process". In Modelling and Simulation 2001: 15th European Simulation Multiconference, $E$. Kercckhoffs and M. Snorek (Eds.). SCS Publication, Erlangen, 1031-1035.

Ginovart M.; D. López; and J. Valls. 2002a. "INDISIM, an individual-based discrete simulation model to study bacterial cultures". Journal of Theoretical Biology 214, 305-319.

Ginovart M.; D. López; J. Valls; and M. Silbert. 2002b. "Simulation modelling of bacterial growth in yoghurt". International Journal of Food Microbiology 73, 415-425.

Ginovart M.; D. López; J. Valls; and M. Silbert. 2002c. "Individual based simulations of bacterial growth on agar plates". Physica A 305, 604-618.

Ginovart M.; A. Gras; and D. López. 2005. "Individual-based modelling of microbial activity to study mineralization of $\mathrm{C}$ and $\mathrm{N}$ and nitrification process in soil". NonLinear Analysis: Real World Applications 6, 773-795.

Ginovart M.; D. López; A. Giró; and M. Silbert. 2006. "Flocculation in brewing yeast: a computer simulation study" Biosystems 83, 51-55.

Gras A. 2004. "INDISIM-SOM. Un model discret per a l'estudi de la dinàmica de la materia orgànica i la nitrificació en sols". PhD Thesis, Lleida University, Spain.
Gras A.; and M. Ginovart M. 2004. "Discrete simulation model to study heterotrophic microbial activity in soil". In Applied Simulation and Modelling, M.H. Hamza (Ed.). IASTED Acta Press, Anaheim, 125-130.

Hadas A., J.A.E. Molina; S. Feigenbaum; and C.E. Clapp. 1992. "Factors affecting nitrogen immobilization in soil as estimated by simulation models". American Journal of Soil Science Society 56, 1481-1486.

Nannipieri P.; S. Grego; B. Ceccati. 1990. "Ecological significance of the biological activity in soil". In Soil Biochemistry 6. Bollag and Stotzky (Edz.). Marcel Dekker, Inc., 293-355

Neergaard A.; L.S. Hauggaard-Nielsen; J. Jensen; and J. Magid. 2002. "Decomposition of white clover (Trifolium repens) and ryegrass (Lolium perenne) componenets: $\mathrm{C}$ and $\mathrm{N}$ dynamics simulated with DAISY soil organic matter submodel". European Journal of Agronomy 16, 43-55.

Pansu M.; Z. Sallih; and P. Bottner. 1998. "Modelling of soil nitrogen forms after organic amendments under controlled conditions". Soil Biology and Biochemistry 30, 19-29.

Schmidt E.L. 1982. "Nitrification in Soil". In Nitrogen in agricultural soils. Agronomy $\mathrm{n}^{\mathrm{o}}$ 22. Stevenson (Ed.). American Society of Agronomy, Madison, 253-289.

Smith P.; J.U. Smith; D.S. Powlson; W.B. McGill; J.R.M. Arah; O.G. Chertov; K. Coleman; U. Franko; S. Frolking; D.S. Jenkinson; L.S. Jensen; R.H. Kelly; H. KleinGunnewiek; A.S. Komarov; C. Li; J.A.E. Molina; T. Mueller; W.J. Parton; J.H.M. Thornley; and A.P. Whitmore. 1997. "A comparison of the performance of nine soil organic matter models using datasets from seven long-term experiments". Geoderma 81, 153-225.

Vidal M. 1995. "Mineralització del nitrogen organic dels fangs precedents de la depuració d'aigües residuals urbanes: efectes del tipus de sòl i del contingut en $\mathrm{Cr}$ del fang". Technical project, Lleida University, Spain.

\section{AUTHOR BIOGRAPHIES}

ANNA GRAS was born in Barcelona, Spain and went to the University of Lleida, where she studied Agricultural Engineering obtained her degree in 1989 and her $\mathrm{PhD}$ in 2004. She is working at the College of Agriculture of Barcelona in the Teaching staff Category of University School Full Lecture, since 1992. She is developing the computer model INDISIM to be applied in the study of organic matter (soil and compost).

MARTA GINOVART was born in Tortosa (Tarragona), Spain. She went to the Universitat Autònoma de Barcelona where she studied Mathematics and she obtained her degree in 1985. In 1996 she achieved her PhD in Simulation in Sciences at the Universitat Politècnica de Catalunya. She is working in the Department of Applied Mathematics of this university with the position of University School Professor. She has developed different versions of INDISIM to deal with diverse microbial systems.

Both are members of the research group SC-SIMBIOComplex systems. Discrete simulation of biological systems (http://mie.esab.upc.es/mosimbio). 